doi:10.7592/FEJF2010.45.gunnell

\title{
SAGNAGRUNNUR: A NEW DATABASE OF ICELANDIC FOLK LEGENDS IN PRINT
}

\author{
Terry Gunnell
}

\begin{abstract}
One of the main problems with researching "traditional" Icelandic legends (apart from the fact that only about $3 \%$ of them are available to people who cannot read Icelandic) is that up until very recently there has been no archive of folk legend material in Iceland. This has meant that the only way to find material on legends of a particular type, gender and job-related distribution of storytellers, distribution of legends, local beliefs and so on has been to plough through all the various collections, and listen to all of the tapes in the Arnamagnæan Institute in Reykjavík, a task daunting enough to put even the most dogged researcher off. Matters, however, are beginning to change in Iceland. Over the last five years, folklorists at the University of Iceland have been working on two large databases of printed and recorded legendary material, each containing over 10,000 entries. The plan is that these databases will eventually be linked, and connected to a mapping programme allowing immediate distribution analysis. In the following article, the situation in Iceland past and present will be analysed, and the draft form of the database of printed material (Sagnagrunnur) presented, along with a review of the possibilities that this will open up for scholars both in Iceland and abroad. At the same time as outlining the advantages of such an approach, some discussion will be made of the difficulties regarding such a database, and the potential weaknesses that need to be considered.
\end{abstract}

Key words: Iceland, database, folk belief, legends, mapping

There is a particular characteristic of the Icelandic people which strikes most visiting foreigners the moment they try to buy a drink in a busy bar, or board a bus in a blizzard. It is a feature that strikes a note of pride in the hearts of many Icelanders, even though, in the academic field at least, it can be both a set of shackles and a pair of blinkers. The feature in question is that of having to take an "individual" path, pretending that it has never been previously trodden, only to end up falling in the same hole that every other traveller has previously ended up in. It is a feature that shines like a beacon in the individual use of the expression "Íslendingar" (Icelanders), rather than "Ísland" (Iceland), when talking of the nation. Everyone is individual; everyone is a leader; everyone has to make the same mistakes (especially bankers); every man is an island. 
In the field of Icelandic folkloristics, it might be argued that this feature slowed potential progress down considerably, not least during the first half of the last century, at a time when it was understandably important for everything to be classed as "Icelandic" rather than "Nordic", "European" or even a local feature of a particular part of Iceland. This was a period when the concept of regional identity was side-lined for the greater good, and also a time when Iceland went out of its way to prove it could "go it alone". As a result, it appears that little real notice was taken of those features in Icelandic folklore and culture that were shared with other nations around us; few comparisons of any kind were made by Icelandic scholars (except, perhaps, in a limited fashion in Einar Ólafur Sveinsson's Um íslenskar pjóðsögur (1940). Outside Árni Böðvarsson's and Bjarni Vilhjálmsson's six-volume edition of Jón Árnason's collection of folk tales (1954-1961), few editions of folk tales ${ }^{1}$ paid any attention to the forms of international classification that were being developed for folk tales and folk tale motifs in Northern Europe, from Aarne and Thompson onwards. This approach is perhaps most clear in Íslenskt pjóðsagnasafn (Ólafur Ragnarsson et al. 2000) and the recent translation of Einar Ólafur's work (2003), which, even today, continue to ignore the central classification work of figures like Christiansen (1958) and Lauri Simonsuuri (1961) when discussing "Icelandic" legends and folk belief.

Even among themselves, it seems that the early collectors and academics could not agree on what form of terminology should be used for folk tales. Throughout the last century, one regularly heard talk of "pjóðsögur og ævintýri” (folk tales and wonder tales), "pjóðsögur og sagnir" (folk tales and legends), and then "pjóðsögur" (folk tales) in the meaning of both legends and wonder tales (which is the agreed form today). Furthermore, while it might be a bit much to expect all the folk-tale collectors to consider referring to foreign collections of legends in their work, there was still little or no system of cross-referencing even to the original two-volume collection of folk tales published by Jón Árnason during 1862-1864. In short, every collector seems to have behaved like the first settler in an uncharted territory.

This weakness does nothing to detract from the fact that Iceland's folk tale material collected and published from the time of Landnámabók onwards, by figures like Ari fróði, Snorri Sturluson, Árni Magnússon, Konrad Maurer, Jón Árnason, Sigfús Sigfússon, Porbergur Porðarson, and (more recently) Rakel Pálsdóttir, is one of the country's great national cultural treasures. Arguably, it stands alongside the sagas, the Eddic poems, and the materials preserved within Pjóðminjasafnið. The published collections alone contain over fifteen thousand legends, alongside several hundred wonder tales. There is as much material again in manuscript and sound form in the sound and manuscript 
archives at the Árni Magnússon Institute in the University of Iceland, and the manuscript department (Handritadeild) of the National Library (Djóðminjasafn). Taken together, this material gives an invaluable insight in the worldview, lives, beliefs, attitudes and values of the Icelanders living in the rural community of the past. In international terms, this is no small amount of material. However, unlike the sagas and the Eddic poems, only about $5 \%$ of this material is accessible to people who can not speak Icelandic. Very little has been translated, outside the first two volumes of Jón Árnason's collection.

Why should any foreigner want access to such material? As noted above, like the sagas, the Eddic poems and the material in Pjódminjasafn, it is an invaluable social, historical and cultural treasure trove for Icelanders (if they can get into it). However, what is often ignored is that this material (like the Eddic poems and sagas) also has great international value, and not least because it is full of recognised international motifs and legend types which have been brought to Iceland by people who have had contact with other nations and cultures. This underlines Iceland's place in a wider international context. On one side, like the early Icelandic material, it underlines the mixed roots of the Icelandic people in the Gaelic and Nordic worlds; on the other, it throws a spotlight on Iceland's cultural contacts in more recent times (see, e.g., Gunnell $1998,2001 \& 2004)$. Furthermore, since Iceland is an island that had limited foreign contacts, it is also considered a relik område where earlier forms of folklore material might wash up. The fact that Iceland's international connections were limited and well-documented makes it easier to date this material and trace its path to the country. Here, however, the Icelanders need international cooperation and comparison, something that is also essential to help them isolate exactly what is truly Icelandic in this material. This, in turn, opens up the potential for examining the way material has adapted to the Icelandic social environment and why unique forms should have evolved.

There is no question that Iceland's legendary material is of unique importance, not only for Icelanders but also for foreign scholars. The key problem, however, is that unlike in other neighbouring countries which all have archives, the Icelandic legends have never been thoroughly indexed, catalogued or classified according to any international system such as those developed by the Norwegians (Christiansen 1958), Finns (Simonsuuri 1961; Jauhiainen 1998), Swedes (af Klintberg 1993), Irish (Almqvist 1991) and Scots (Bruford 1967; MacDonald 1994-1995). As noted above, many Icelandic legend collections not only lack indexes, but also any form of cross-referencing. There is no agreed form of reference. In many cases, these collections even lack information about storytellers or the place of origin of legends. In short, as with the bus and the 
bar mentioned at the start, we have a case of valiant Icelanders rushing forward bravely and independently but without any form of interaction.

For any later researcher of folk legends, this was a nightmarish situation. Anyone wanting to research particular international types or motifs simply had to plough through every single one of the various Icelandic collections in the Árnastofnun, which could take weeks or months. As noted above, the situation was very different in neighbouring countries, which not only made use of international classification systems but also had well-developed card archives of all collected legends from a relatively early point. While these catalogues may not be perfect, the situation in neighbouring countries was certainly much better than in Iceland, where the archive material was split across three different institutions (the Árni Magnússon Institute (Árnastofnun), the Ethnology Department of the National Museum (Pjóðháttardeild pjóðminjasafns), and the Manuscript Department of the National Library (Handritadeild), none of which had a complete catalogue of the legends in their charge, let alone any attempt to classify it by any international system.

So much for the past. We can be grateful for the fact that the situation now is very different, thanks in no small measure to the pioneering work of Gísli Sigurðsson and Rósa Porsteinsdóttir in the Árni Magnússon Institute, Professor Bo Almqvist of University College, Dublin, the continued financial support of the Research Fund of the University of Iceland (Rannsóknarsjóður Háskóla Íslands) and the Icelandic Science Council (Rannis), and the diligent work of a large number of other individuals, many of them students of folkloristics in the University of Iceland (Háskóli Íslands). The first steps came from two different sides. On one hand, as part of his own comparative research into Scandinavian and Irish legend types over the past forty years, Bo Almqvist began individually compiling detailed catalogues of all the Icelandic variants of several international legend types, following foreign models in making careful note of all relevant details, ranging from the place of origin of each tale, to the sex and social background of each storyteller, and key points about the form of the legend in each case. Alongside this, in 1994, Gísli Sigurðsson at the Árni Magnússon Institute employed Rósa Porsteinsdóttir to start compiling a basic database of all the material contained in the sound archives, which ranges from social history to riddles, songs, belief accounts and folk tales of all kinds. Both of these examples served as a basis for the work on the new Sagnagrunnur database of all published legends, the work which commenced in the University of Iceland in 1999, largely the result of my own frustration and growing awareness of the failings in the "system" that previously existed.

In short, the Sagnagrunnur (which is still under construction, and hopefully will remain so for many years to come as new material is regularly added, 
even after it has been formally opened) is intended to be the first complete online digital archive of written Icelandic legendary material. As such, it is meant to serve as a brother to the Árni Magnússon Institute Ísmús database of material (the legend section of which is currently being updated to make it a working parallel to the Sagnagrunnur). ${ }^{2}$ In the long run, it is also hoped that the database will include material from the Færoes, Orkney and Shetland, thus forming a wider international North Atlantic island catalogue, which could be placed in connection with other databases from Norway, Scotland and Ireland should they eventually come to be compiled.

Based on six years of recording and classification work by more than twentyfive students and other helpers in addition to myself, the Sagnagrunnur now contains records of more than ten thousand Icelandic legends. It covers over sixty volumes of material (see the bibliography). A typical entry (with a translation) can be seen below (note that as yet all entries are only in Icelandic). As will be noticed immediately, no attempt has been made to replace the existing books by putting the entire text of each legend into the database, something that would have been a waste of both time and space. The intention is simply to provide an easily accessible key and cross-reference to the material that these folk legend collections contain.

Heiti (Title): Missögn um Trölla-Láfa (Another variant of the story of Trölla-Láfi)

Heimild (Source): Jón Árnason, Íslenzkar pjóðsögur og ævintýri, ný útgáfa, rits. Árni Böðvarsson og Bjarni Vilhjálmsson (Reykjavík, 195461), I, 185-186

Heimildarmaður (Informant): "Eftir gamalli konu úr Rangárbingi" ("By an old woman in the Rangárping area")

$\boldsymbol{K y n}$ (Sex): $k v$ (f.)

Heimili (Home): Rang. (Rangár county: Details of individual farms often given)

Sendandi (Collector): Magnús Grímsson (Hdr. 415, 202)(MS number)

Heimili sendanda (Home of sender): Kjós: Mosfell, Mosfellssveit (Kjós county: Mosfell, Mosfell parish)

Skráningarár (Year of recording): 19. öld (19th century)

ML, AT, MI númer (Foreign classification number): IML (Man Kidnapped by Troll Women); IML (Wall or Building Permanently Damaged by Supernatural Being); MI F455 (Trolls); MI G304.2.4.1 (Trolls Cannot Endure Church Bells); TMI N801 (Demon-giants Flee from the Sound of 
the Church Bell); TMI M76 (Mountain Trolls Flee from Sound of Church Bell) (IML refers to as yet unnumbered Icelandic migratory legends not known elsewhere)

\section{Sögustaður (Setting of legend):}

\section{Tímabil (Period in which legend takes place):}

Efnisorð (Key words): tröll, kirkjur, jurtir, ferðalög, kirkjuklukkur, álög (trolls, churches, herbs, journeys, church bells, curses)

Efni (Material): Maður var numin brott af skessum í grasaferð. Létu bær hann sofa á milli sín og blésu i eyru honum með pípum sínum til að trylla hann en tókst ekki. Lést hann einhverju sinni sýkjast, neytti einskis matar og sagðist aðeins batna myndi ef hann fengi níu ára gamlan hákarl og briggja ára gamalt fornskyr. Skessurnar fara bá báðar að sækja betta, önnur norður í land en hin vestur. Á meðan hljóp maðurinn til byggða og að kirkjustað einum. Rétt í bví kom önnur skessan en hann náði að hringja kirkjuklukkunum og settist hún pá á kirkjugarðinn svo fast að hann hrundi. Sagði hún pá: „,Svei pér, skitur, og stattu aldri !” Og bykir pað hafa ræst. (A man was abducted by some troll women when he was collecting herbs and roots. They had him sleep between them, and blew into his ears with their pipes to drive him crazy, but did not succeed. One day, he pretended to be ill, and refused all food, saying he would only get better if he was given nine-year-old sharkmeat and three-year-old curds. The troll women went off to look for this, one going north and the other west. While they were gone, the man ran off back to the settlement and to a church. At that moment, one of the troll women came back, but he succeeded in ringing the church bell, and she sat down on the church wall so hard that it collapsed. Then she said: "Damn you, you shit; may you never stand again!" And people say that this came true.)

\section{Vísur (Verses):}

\section{Not. (Other notes)}

The format, at present in File-Maker Pro, basically follows the format established by Rósa Porsteinsdóttir for the Árni Magnússon Institute Ísmús folklore database, but goes a little further. As can be seen, the record begins with information about the title of the legend, the printed collection in which it is contained, the manuscript number (if that is available), the name, sex and place of abode of the storyteller, and the name and place of abode of the person who collected the account in question. Following this comes reference material about the legend in question: a summary of the story, information about the places where it takes place, and then a list of relevant key words drawn 
from a shared list used by both the Sagnagrunnur and the Ísmús database, something designed to ease future cross-referencing between the two databases. In addition to this, information is provided about any Northern European classification system that the legend (or motifs from it) might belong to (see above); about any available translations; and any international academic work relevant to the legend in question. Finally, the first verse of any poetic material is quoted for quick cross-referencing purposes.

So what exactly will this new database allow us to do? First of all, it will make it possible for scholars to find all variants of a particular motif or international legend type from Iceland within the space of a few seconds rather than several weeks. The same will apply to the use of the key words which will not only benefit folk tale scholars, but also others interested in specific fields such as sports, clothing, housing or festivals. Our plan is to connect the database to a GIS mapping programme (connected to the sýslur (counties) and place names mentioned in the database) which will allow us to see, at the push of a button, not only the distribution of particular legends or motifs but also, for example, that of smaller items, such as the use of the word álfar rather than huldufólk (hidden ones) for the Icelandic 'elves'. The distribution findings can then be analysed in connection to environmental and social factors that might explain any regional differences. In short, among other things, the database will be an important tool for re-opening the field of local folklore and regional identity, something ably demonstrated by Júlíana Magnúsdóttir (2004 and 2008) in her ground-breaking BA and MA dissertations on the legends and legend-tellers of Austur-Skaftafellssýsla, which made some use of the database at an earlier stage.

Alongside such regional analysis, the database will allow us to analyse the repertoires of different storytellers, a field that has, of course, been of increasing importance in folklore research in other countries during the last few decades. It will also make it possible to analyse the connections between the storytellers and their material. Among other things, we will be able to assess statistically whether there seem to be differences between the types of legends told by men and women, and analyse whether certain sorts of legends were connected with particular classes or types of work, and if so the next step might be to examine the function of such a tale for these people. An obvious example is the common connection between the "Midwife to the Fairies" legend, and working midwives (see further Almqvist 2009, which also made use of the database). Alongside this, we will have a chance to analyse how legends have actively passed between friends and relations, and how they have changed on the way. 
Something else that the database will enable us to do statistically is to analyse effectively the type of legendary material that was chosen for the earliest volumes of folk tales that were published in Iceland. As is well known from studies undertaken abroad (see, e.g., Hodne 1979), there was often a slightly unconscious political agenda behind the earliest collections, especially those undertaken in countries like Iceland, Norway, Denmark, Ireland, Scotland and Germany, where the publication of these books had a key role to play in political struggles for independence. The legends contained in them were not only seen as underlining the nation's roots in a distant golden past, but also as connections with greatness (such as the Grimms' collection) while revealing the special qualities of the common people, their individuality and independence. In short, the collections helped to create a useful "national character" (see further Gunnell 2010 on the first Icelandic collections). Statistical and stylistic comparison between the material contained in the first two volumes of Jón Árnason and that which appears in both later Icelandic collections and foreign collections is likely to be very revealing. Here, too, the Sagnagrunnur can help greatly.

Most important of all, however, is the fact that when the standardised database eventually becomes formally available on the internet, ${ }^{3}$ it will not only make this cultural treasure trove immediately accessible to a new audience, not only to students and teachers at all levels of schooling, but also to those working in the tourist industry and interested in bringing the landscape and heritage of the countryside back into focus. Furthermore, the original longterm intention was that the appearance of the database on the web would finally make the legends recorded in Iceland also easily accessible to the rest of the world for the first time. As noted above, this is especially important, not only because of Iceland's great international value as a potential relik område, but also because we all have a great deal to gain from international folklorists bringing their wide range of experience to bear on Icelandic material, something already ably demonstrated in the invaluable work of figures like Bo Almqvist, Jacqueline Simpson, John Lindow and Timothy Tangherlini.

Here, however, we reach another cultural problem. As noted above, up until now, all that has been available to those foreign folklorists who do not speak Icelandic are translations of a number of legends mainly taken from the first two volumes of Jón Árnason's collection of folk tales which have appeared in English, German or Scandinavian. As also noted, it is questionable exactly how typical these two volumes were of Icelandic legends as a whole. Similar to other Icelandic folk tale collections, the database, with all its international potential, is at present in Icelandic, and as such, it remains near totally inac- 
cessible to anyone abroad who can not speak or read the language. While it is a relatively easy matter to translate the framework and the key words into English, the same can not be said for the nearly twelve thousand legend summaries themselves which form the basis of the work. Translation costs money, and as yet it has proved impossible to get any official funding for the translation of the material in the database, even before the time of the Icelandic financial collapse. Translation, like recording, does not count as research in itself. It would seem that the local authorities are quite happy for the legends collected in Iceland to remain locked away from foreign view and foreign research, as Icelandic as they can be. In short, for some it seems that the blinkers are still as firmly in place as they were in the nineteenth century. One can only hope for outside interest in the future if these dreams are to be brought to fruition.

\section{NOTES}

1 See, e.g., Arngrímur Friðrik Bjarnason 1909 \& 1954-1959; Einar Guðmundsson 1932; Guðni Jónsson 1957-1969; Hannes Porsteinsson \& Jón Porkelsson \& Ólafur Davíðsson \& Pálmi Pálsson \& Valdimar Ásmundsson 1890-1898; Helgi Guðmundsson \& Árngrímur Friðrik Bjarnason 1933-1949; Jón Thorarensen (ed.) 1971; Jón Porkelsson 1956; Ólafur Davíðsson 1987; Oddur Björnsson 1977; Sigfús Sigfússon 1982-1993; and Sigurður Nordal \& Pórbergur Pórðarson 1962.

${ }^{2}$ See: http://ismus.musik.is/Apps/WebObjects/ISMUS.woa/2/wo/0RxUD1tiFjCKB3PuiWuUz0/ 0.Look.12, last accessed on 10 August 2010.

${ }^{3}$ A draft form of the database is at present available at http://notendur.hi.is/terry/ database/sagnagrunnur.htm, last accessed on 10 August 2010. 


\section{REFERENCES}

Including a list of works recorded, and classification systems used in the Sagnagrunnur

Af Klintberg, Bengt 1993. The Types of the Swedish Folk Legend: Report on an Unfinished Catalogue. Arv: Nordic Yearbook of Folklore, Vol. 49, pp. 67-74.

Almqvist, Bo 1991. Crossing the Border: A Sampler of Irish Migratory Legends about the Supernatural. Béaloideas: The Journal of the Folklore of Ireland Society, Vol. 59 The Fairy Hill is on Fire!, pp. 209-279.

Almqvist, Bo 2009. Midwife to the Fairies (ML 5070) in Icelandic Tradition. In: T. Gunnell (ed.) Legends and Landscape. Reykjavík: Háskólaútgáfan, pp. 273-342

Arngrímur Friðrik Bjarnason 1909 \& 1954-1959. Vestfirzkar pjóðsögur I-III. [Folk Tales from the West Fjords I-III.] Ísafirður: Arngrímur Bjarnason and Oddur Gíslason \& Reykjavík: Ísafoldarprentsmiðja.

Bruford, Alan 1967. Scottish Gaelic Witch Stories: A Provisional Type List. Scottish Studies, Vol.11, pp. 13-47.

Christiansen, Reidar Thoralf 1958. The Migratory Legends: A Proposed List of Types with a Systematic Catalogue of the Norwegian Variants. Folklore Fellows' Communications, 175. Helsinki: Suomalainen Tiedeakatemia.

Einar Guðmundsson 1932. Íslenskar bjóðsögur 1-4. [Icelandic Folk Tales 1-4.] Reykjavík: Leiftur.

Einar Ólafur Sveinsson 1940. Um íslenskar pjóðsögur. [On Icelandic Folk Tales.] Reykjavík: Sjóður Margrétar Lehmann-Filhés.

Einar Ólafur Sveinsson 2003. The Folk-stories of Iceland. In: B. Sigurður Benedikz et al. (transl.) \& E. G. Pétursson \& A. Faulkes (eds.) Text series / Viking Society for Northern Research, 16. London: Viking Society for Northern Research.

Guðni Jónsson 1957-1969. Íslenskir sagnapættir og pjóðsögur I-XII. [Icelandic Historical Legends and Folk Tales I-XII.] Reykjavík: Ísafoldarprentsmiðja.

Gunnell, Terry 1998. The Return of Sæmundur: Origins and Analogues. In: J. Jónsson et al. (eds.) Pjóðlíf og pjóðtrú:Ritgerðir helgaðar Jóni Hnefli Aðalsteinssyni. [Folk Life and Folk Belief: Articles Dedicated to Jón Hnefill Aðalsteinsson.] Reykjavík: Pjóðsaga, pp. 87-111.

Gunnell, Terry 2001. Mists, Magicians and Murderous Children: International Migratory Legends Concerning the 'Black Death' in Iceland. In: S. Ó Catháin (ed.) Northern Lights: Following Folklore in North Western Europe: Essays in Honour of Bo Almqvist. Dublin: University College Dublin Press, pp. 47-59.

Gunnell, Terry 2004. The Coming of the Christmas Visitors: Folk Legends Concerning the Attacks on Icelandic Farmhouses Made by Spirits at Christmas. Northern Studies, Vol. 38, pp. 51-75.

Gunnell, Terry 2010. Daisies Rise to Become Oaks: The Politics of Early Folklore Collection in Northern Europe. Folklore, Vol. 121, pp. 12-37.

Hannes Porsteinsson \& Jón Porkelsson \& Ólafur Davíðsson \& Pálmi Pálsson \& Valdimar Ásmundsson 1890-1898. Huld: Safn alpýðlegra fraeða ízlenzkra. [Huld: A Collection of Icelandic Folklore.] Reykjavík: Sigurður Kristjánsson. 
Helgi Guðmundsson \& Árngrímur Friðrik Bjarnason 1933-1949. Vestfirskar sagnir, 1-3. [Legends from the West Fjords 1-3.] Reykjavík: Bókaverzlun Guðm. Gamalíelssonar and Bókaforlagið Fagurskinna.

Hodne, Ørnulf 1979. Jørgen Moe og folkeeventyrene: En studie i nasjonalromantisk folkloristikk. [Jørgen Moe and the Wonder Tales: A Study into National Romantic Folkloristics.] Oslo: Universitetsforlaget.

Jauhiainen, Marjatta 1998. The Type and Motif Index of Finnish Belief Legends and Memorates. Folklore Fellows' Communications, 267. Helsinki: Academica Scientiarum Fennica.

Jón Árnason 1954-1961. Íslenzkar pjóðsögur og ævintýri 1-6. [Icelandic Folk Tales and Fairy Tales 1-6.] Reykjavík: Pjóðsaga.

Jón Thorarensen (ed.) 1971. Rauðskinna hin nýrri: Pjóðsögur, sagnapættir, pjóðhættir og annálar 1-3. [The New Redskin: Folk Tales, Legendary Histories, Folk Traditions and Annals 1-3.] Reykjavík: Pjóðsaga.

Jón Porkelsson 1956. Pjóðsögur og munnmæli. [Folk Tale Collection.] Reykjavík: Bókfellsútgáfan.

Júlíana Póra Magnúsdóttir 2004. Sagnir milli Sanda: Rannsókn á sögnum, sagnamönnum og pjódtrú i Skaftárhreppi. [Legends Between the Sands: Research Into the Legends, Storytellers and Folk Beliefs of Skaftá County.] Unpublished BA essay: Háskóli Íslands, Félagsvísindadeild.

Júlíana Póra Magnúsdóttir 2008. Saga til næsta bæjar: Sagnir, samfélag og pjóðtrú sagnafólks frá austurhéraði Vestur-Skaftafellssýslu. [A Well-Known Story: Legends, Society and The Beliefs of Legend Storytellers in the Eastern part of West Skaftafell County.] Unpublished MA dissertation.

MacDonald, Donald Archie 1994-1995. Migratory Legends of the Supernatural in Scotland: A General Survey. Béaloideas: Journal of the Folklore Society of Ireland, Vol. 62-63, pp. 29-79.

Ólafur Davíosson 1987. In: Porsteinn M. Jónsson \& Jónas Rafnar \& Bjarni Vilhjálmsson (eds.) Pjóðsögur1-4. [Folk Tales 1-4.] Reykjavík: Pjóðsaga.

Ólafur Ragnarsson \& Sverrir Jakobsson \& Margrét Guðmundsdóttir. 2000. Islenskt bjóðsagnasafn [A Collection of Icelandic Folk Legends], Vol. 1-5. Reykjavík: Vaka-Helgafell.

Oddur Björnsson 1977. Pjóðtrú og bjóðsagnir. [Folk Belief and Folk Legends.] Akureyri: Oddur Björnsson.

Sigfús Sigfússon 1982-1993. In: Ó. Halldórsson et al. (eds.) Íslenskar pjóðsögur og sagnir 1-11. [Icelandic Folk Tales and Legends 1-11]. New ed. Reykjavík: Pjóðsaga.

Sigurður Nordal \& Pórbergur Pórðarson 1962. Gráskinnahin meiri I-IV. [The Greater Greyskinn I-IV. Reykjavík: Pjóðsaga.

Simonsuuri, Lauri 1961. Typen- und Motivverzeichnis der finnischen mythischen Sagen. Folklore Fellows' Communications, 182. Helsinki: Academica Scientiarum Fennica.

Thompson, Stith 1981. The Types of the Folktale: A Classification and Bibliography: Antti Aarne's Verzeichnis der Märchentypen (Folklore Fellows' Communications, Vol. 3). Folklore Fellows' Communications, 184. Helsinki: Academica Scientiarum Fennica. 
Torfhildur Porsteinsdóttir Holm \& Finnur Sigmundsson 1962. Pjóðsögur og sagnir. [Folk Tales and Legends.] Bók mánaðarins: 1962, marz. Reykjavík: Almenna bókafélagið.

Porsteinn Erlingsson 1954. Pjóðsögur Porsteins Erlingssonar. [Porsteinn Erlingsson's Folk Tales.] Reykjavík: Ísafoldarprentsmiðja.

Porsteinn M. Jónsson 1964-1965. Grima hin nýja: Safn pjóðlegra fræða íslenzkra 1-10. [The New Gríma: A Collection of Icelandic Folklore 1-10]. Reykjavík: Pjóðsaga. 